\title{
Atrial and Brain Natriuretic Peptides of Secretory Cardiomyocytes in Salt Loading in Experiment
}

\author{
DOI: $10.17691 / \mathrm{stm} 2016.8 .3 .05$
}

Received April 26, 2016

\begin{abstract}
M.V. Galkina, PhD, Senior Researcher, Electron Microscopy Unit, Central Scientific Research Laboratory;
L.B. Snopova, DSc, Associate Professor, Head of Morphology Department, Central Scientific Research Laboratory;

N.N. Prodanets, PhD, Senior Researcher, Morphology Department, Central Scientific Research Laboratory;

R.D. Lapshin, PhD, Associate Professor, Head of Experimental Modeling Department, Central Scientific

Research Laboratory;

I.I. Belousova, PhD, Researcher, Experimental Modeling Department, Central Scientific Research Laboratory;

D.A. Abrosimov, Tutor, Department of Histology with Cytology and Embryology;

M.L. Bugrova, PhD, Associate Professor, Head of Electron Microscopy Unit, Central Scientific Research Laboratory
\end{abstract}

Nizhny Novgorod State Medical Academy, 10/1 Minin and Pozharsky Square, Nizhny Novgorod, 603005,

Russian Federation

The aim of the investigation is to assess the influence of salt load on atrial (ANP) and brain (BNP) natriuretic peptide production in granules of secretory cardiomyocytes in rats.

Materials and Methods. The experiments were carried out on 14 white out-bred male Wistar rats weighing 280-300 g. During the experiment all the animals were treated with standard-feed diet and had unlimited access to food and water. $\mathrm{NaCl}$ solution was introduced per os in the dose of $1 \mathrm{~g}$ per $1 \mathrm{~kg}$ of body mass during 14 days. Arterial pressure (AP) was measured noninvasively using a tail-cuff method. ANP and BNP production of atrial cardiomyocytes was studied by means of immunohistochemistry, transmission electron microscopy, immunocytochemistry. There was performed a morphometric analysis of granules containing peptides (A-type - "mature, storing" and B-type - "dissolving").

Results. Increase in the number of granules with ANP and decrease in those with BNP accompanied by elevated AP was revealed 14 days after $\mathrm{NaCl}$ intake as compared to intact animals.

Conclusion. Natriuretic peptides metabolism is regulated by various mechanisms. Early BNP release does not promote AP reduction due to compensatory mechanism disturbance in salt-induced arterial hypertension. Increase in ANP production occurs under the influence of renin-angiotensin-aldosterone system and elevated AP. The present data can indicate adaptive reaction in response to salt loading.

Key words: atrial natriuretic peptide; ANP; brain natriuretic peptide; BNP; salt loading.

Atrial (ANP) and brain (BNP) natriuretic peptides are bioactive substances secreted in the heart, which cause natriuretic, vasodilatory, hypotensive effects and are antagonists of renin-angiotensin-aldosterone system (RAAS) [1, 2]. The hormones have similar molecular structure, receptor apparatus and mechanism of action $[3,4]$. Researchers have found that natriuretic peptide secretion into the blood increases in arterial hypertension $(\mathrm{AH})$ and their plasma concentration directly correlates with the severity of cardiac dysfunction [5-8]. However, the role of NP in AH pathogenesis as well as the causes of development and the progress of this pathology are not completely clear $[9,10]$.

The interrelation of arterial pressure (AP) and salt load has been well studied. It has been noted that in some people and experimental animals salt intake can easily provoke AP elevation but it has no effect in others [11-13]. High sensitivity to $\mathrm{NaCl}$ intake is expressed as significant AP elevation and is a risk factor in the development of $\mathrm{AH}$, myocardial infarction, hemorrhagic stroke $[14,15]$. Revealing this sensitivity in a clinic enables patients to be administered most effective therapy within a short time. Experimental studies in this field are determined by the search for new criteria of early diagnosis and are of great current interest [16, 17].

The study of natriuretic peptide in salt loading contributes to understanding $\mathrm{AH}$ pathogenesis [18]. Most often ANP and BNP are studied using biochemical methods [8, 19-22]. However, their plasma concentration does not always coincide with the quantitative characteristics of peptides in the heart [23]. Using the method of counting immunolabeled granules of different types provides the possibility to evaluate the contribution of ANP and BNP to cardio-vascular balance control in pathologic conditions. It should be noted that the studies where both hormones are analyzed are the most relevant $[24,25]$.

For contacts: Mariia V. Galkina, e-mail: maryrax82@gmail.com 
The aim of the investigation is to assess the influence of salt load on atrial and brain natriuretic peptide production in granules of secretory cardiomyocytes in rats.

Materials and Methods. The experiments were carried out according to the rules of Good Laboratory Practice on 14 white out-bred male Wistar rats weighing 280-300 g. The work was performed in full accordance with the Ethical Principles of the European Convention for Protection of Vertebrate Animals used with Experimental and other Scientific Purposes (the Convention took place in Strasbourg on 18.03.1986 and was confirmed in Strasbourg on 15.06.2006). During the experiment all the rats were treated with standard-feed diet, had unlimited access to food and water and were housed under conditions of twelve-hour dark/light period. The control group $(n=8)$ included intact animals, in the experimental group $\mathrm{NaCl}$ solution was introduced to the rats per os in the dose of $1 \mathrm{~g}$ per $1 \mathrm{~kg}$ of body mass during 14 days. AP was measured noninvasively using Nonlnvasive Blood Pressure Meter LE5001 (Panlab, Spain) with a tail-cuff before salt administration and 14 days after it. The animals were removed from the experiment by decapitation method. The samples for further analysis were taken 14 days after AP measuring.

To confirm antibody response specificity there was performed immunohistochemical analysis of the right atrial tissue samples of intact rats. The samples were fixed in $10 \%$ neutral formalin for $48 \mathrm{~h}$, washed in running water, dehydrated in ethyl alcohol of increasing concentrations and embedded in paraffin. Histological sections, 5-7 $\mu \mathrm{m}$ thick, were obtained on a sliding microtome Leica SM 2000R (Leica Microsystems, Germany). Antigen reactivation was carried out by method of thermal retrieval using a citrate buffer with $\mathrm{pH}=6.0$ (Novocastra Laboratories, UK) [26]. For ANP visualization we used primary polyclonal antibodies to ANP, Rabbit anti-Atrial Natriuretic Factor (1-28) (rat) with 1:50 working dilution. Rabbit anti-Brain Natriuretic
Peptide-32 (Rat) Serum with 1:100 working dilution (Peninsula Lab. Inc., Bachem, USA) was used for visualization of BNP. Detection was performed using Peroxidase Detection System (Novocastra Laboratories, UK) in accordance with the manufacturer's instructions. Negative control was carried out by exclusion of primary antibodies.

Electron microscopy of the right atrial tissue samples of intact and experimental animals was performed using standard methods. The samples were fixed in $2.5 \%$ phosphate-buffered solution of glutaric dialdehyde $(\mathrm{pH}=7.4)$ and in $1 \%$ solution of $\mathrm{OsO}_{4}$ with subsequent embedding into the mix of Epon and Araldit [27]. ANP and BNP cell localization was revealed on ultrathin sections using the above-mentioned polyclonal antibodies to ANP and BNP. Protein A conjugated with colloidal gold (Protein-A/Gold, $15 \mathrm{~nm}$; EM Grade, Electron Microscopy Sciences, USA) was used as second antibodies [9]. Reactions were performed separately for each peptide. Sections processed with only second antibodies served as control. They were uranyl acetate and lead citrate contrasted and analyzed under the electron microscope Morgagni 268D (FEl, USA) using AnalySIS software.

A quantitative analysis of the two types of granules with peptides in atrial cardiomyocytes (A-type "mature, storing" and B-type - "dissolving") was performed by counting in fields of vision $(38 \times 38 \mu \mathrm{m})$ $[24,28]$.

The findings were statistically processed with Statistica 10.0 software using Wilcoxon test and MannWhitney U-test.

Results. After 14 days we observed changes in AP in experimental group as compared to the initial indexes: in some animals AP $(n=3)$ elevated from 98 to $105 \mathrm{~mm} \mathrm{Hg}$, in others $(n=3)$ it decreased from 98 to $84 \mathrm{~mm} \mathrm{Hg}$ $(p<0.05)$. The present study has involved the animals with significantly elevated arterial pressure (by 10\% compared to intact ones) for further investigation.
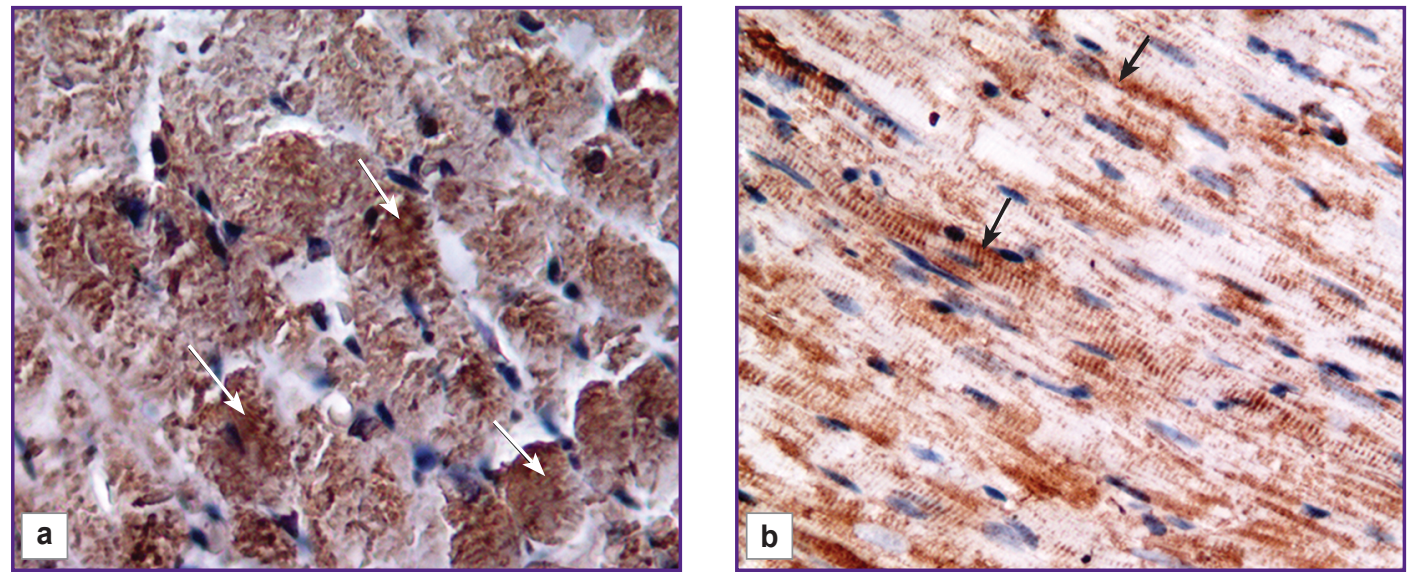

Figure 1. Immunohistochemical staining of atrial natriuretic peptide (a) and brain natriuretic peptide (b) in the right atrial cardiomyocytes of intact rats (arrows); $\times 400$ 


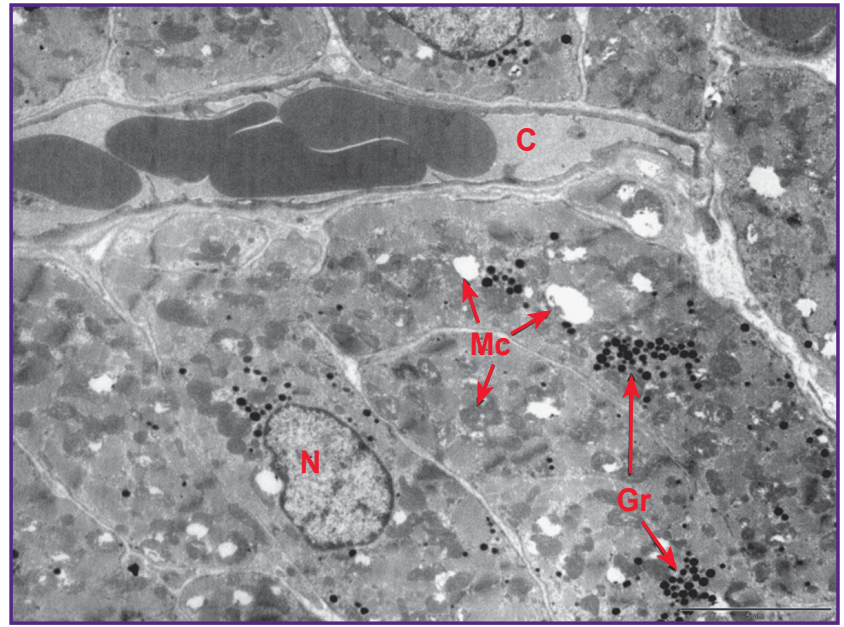

Figure 2. Ultrastructure of the right atrial myocardium after 14 days of salt loading: granules $(\mathrm{Gr})$; capillary $(\mathrm{C})$; mitichondria (Mc); nucleous $(\mathrm{N}) ; \times 3,500$

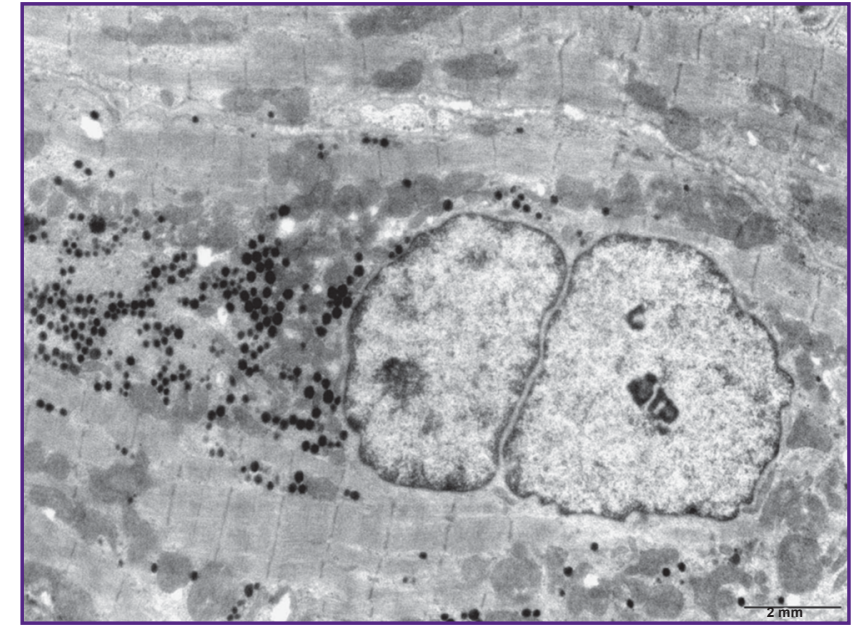

Figure 3. Secretory granules in the right atrial cardiomyocyte after 14 days of salt loading; $\times 5,600$

Proportion of A- and B-type granules containing atrial natriuretic peptide and brain natriuretic peptide in the atrial myocytes of rats after salt loading

\begin{tabular}{|ccccc}
\hline \multicolumn{1}{c}{ Experiment groups } & \multicolumn{2}{c}{ Granules containing ANP } & \multicolumn{2}{c}{ Granules containing BNP } \\
& Type A & Type B & Type A & Type B \\
\hline Intact animals $(n=8)$ & $65.75 \pm 19.50$ & $38.90 \pm 19.63$ & $16.0 \pm 5.43$ & $7.53 \pm 2.69$ \\
& $63 \%$ & $37 \%$ & $68 \%$ & $32 \%$ \\
\hline \multirow{2}{*}{14 days of salt loading $(n=3)$} & $117.96 \pm 33.5^{*}$ & $88.83 \pm 28.06^{*}$ & $6.42 \pm 3.42^{*}$ & $3.65 \pm 2.79^{*}$ \\
& $58 \%$ & $42 \%$ & $64 \%$ & $36 \%$ \\
\hline
\end{tabular}

* value differences are statistically significant compared to intact animals, $p<0.05$.

ANP- and BNP-immunoreactivity was found in the right atrium of intact rats with prevailing localization in the perinuclear space of cardiomyocytes. Notably, ANPreaction (Figure $1(\mathrm{a})$ ) was more intense than that of BNP (Figure 1 (b)).

Electron-microscopic analysis of the right atrium of experimental animals showed the following changes in cardiomyocyte structure. Euchromatin with ill-defined aggregation to the periphery prevailed in the nucleus, mostly with no nucleoli. Karyolemma was smooth or with slight invaginations (Figure 2). A significant number of cytoplasmic granules was visually detected in sarcoplasm. Cisterns of sarcoplasmic reticulum were not extended. There prevailed swollen mitochondria with matrix clarification, cristae disorientation and fragmentation. Single giant mitochondria were also observed. Myofibrils were clearly defined in most cardiomyocytes. In general, sarcolemma had no visible changes, there were occasional folds and a few thinning areas. Moderate intercellular edema was detected (Figure 3).

After two weeks of salt loading there were detected morphometric changes in granules of the right atrial secretory cardiomyocytes, containing immunoreactive material. Granules with ANP of A-type were found to increase by $79 \%$ and B-type by $128 \%$, their total number increased by $200 \%$. Notably, the proportion of type A and B amounted to 58 and $42 \%$, respectively, in intact animals it was 63 and $37 \%$. The number of granules containing BNP decreased compared to the intact group: A-type by $60 \%$, B-type by $52 \%$, the total number decreased by $43 \%$. The proportion of type A and B amounted to 64 and $36 \%$, respectively, in intact animals it was 68 and $32 \%$ (See the Table).

Discussion. The revealed division of experimental animals into two groups according to AP changes confirms the data on salt-sensitivity reported in literature $[29,30]$. Sensitivity to $\mathrm{NaCl}$ is caused by feature of kidney function, disturbance of sympathetic nervous system, prostaglandin synthesis, RAAS activity [31-33]. A group of salt-sensitive animals with elevated AP was studied in this investigation.

ANP and BNP response to the influence of various factors (ischemia, $\mathrm{AH}$ ) and changes in their plasma concentrations are known to be similar in many ways $[1,9,34]$. This can be explained by the fact that both 
peptides have similar structures and mechanisms of action, use the same cellular receptors for producing their effects, they are stored together in granules of secretory cardiocytes [24, 35]. However, scientific literature provides information about the differences in ANP and BNP properties in cardiovascular pathology $[5,6,36]$. In this study we have established diverse response of peptides in the right atrial myocytes of rats to salt.

In the experimental group increase in mature and dissolving forms of granules with ANP, compared to the intact animals, suggested active accumulation and release of the hormone. Therewith, A- and B-type proportion indicated processes shifting to its release. It has been established [37] that salt loading as well as AP elevation are factors promoting hypergranulation of atrial myocytes and ANP secretion. The other authors [38] have revealed $40 \%$ increase in AP, $351 \%$ increase in peptide granules and $100 \%$ increase in plasma level of the hormone in C57BL/6 mice (mouse model with human metabolic syndrome) after 9 weeks of $\mathrm{NaCl}$ intake. Clinical investigations demonstrate that salt loading activates RAAS in kidneys [39-42]. RAAS activation along with elevated AP is likely to be the main stimulus affecting ANP accumulation and release in experimental animals.

Analysis of immunolabeled granules with BNP in our investigation revealed decrease in the processes of its accumulation and release. According to the literature data concerning BNP activation in response to cardiovascular pathology development [43-45], this may speak of early secretion of the hormone. Apparently, it is intended to reduce AP. However, we observed its increase in the experimental group. Scientific literature and clinical practice still provide no answer to "the hormonal paradox" occurring in hypertension: high NP concentrations do not produce hypotensive effect [18]. Decrease in natriuretic peptide receptor density is considered to be one of the reasons [46] but this has not been proved sufficiently. Researchers have reported that normal compensatory mechanism of AP control by natriuretic peptides is suppressed by high-salt diet [38] due to changes in kidneys $[47,48]$. Precisely this is the fact explaining the absence of hypotensive effect of early BNP release and high ANP level after 14 days of our experiment.

The authors of the study [49] have demonstrated an important role of $\mathrm{Ca}^{2+}$ ions in BNP response formation. Increased flow of $\mathrm{Ca}^{2+}$ ions to their matrix leading to cell death occurs through the mitochondrial calcium uniporter located in the mitochondrial membrane. BNP exerts an inhibitory effect on this channel, thereby preventing cardiomyocyte death [50]. The absence of marked changes in ultrastructure of the right atrium noted in the present study can be associated with a cardioprotective effect of BNP established in the earlier stages of the experiment. Simultaneously, destructive changes in mitochondria may indicate disturbance of high-energy compound synthesis, which leads to decrease in BNP formation and release. In has been reliably established [3] that enhanced transport of $\mathrm{Ca}^{2+}$ ions promotes synthesis increase and formation of secretory granules with ANP and this is confirmed by the increase in total quantity of granules with ANP found after 14 days of our experiment.

Our study revealed various reactions of natriuretic peptides in salt loading. In salt-sensitive DOCA rats increase in the plasma level of ANP was detected after 2 weeks, while BNP level remained unchanged, with mRNA expression of both peptides in the myocardium being similar to that of the control [36]. According to the hypothesis, not only increased liquid volume, AP, hypertrophy and arrhythmia trigger synthesis and release of natriuretic peptides [51] but also oxygen gradient and myocardial energy metabolism [52, 53]. Apparently, salt load provokes shift of the above-mentioned factors in the right atrial cardiomyocytes, which has affected ANP and BNP variously in our experiments.

Thus, the obtained findings speak of diverse peptide response in granules of the right atrial myocytes of rats under the influence of salt. The observed decrease in BNP production and increase in ANP accumulation and release are likely to indicate adaptive reaction of the heart to salt diet.

Conclusion. Natriuretic peptide metabolism regulation is carried out by various mechanisms. The present study allows us to conclude that early release of brain natriuretic peptide does not promote AP reduction due to disturbance of compensatory mechanism in salt-induced arterial hypertension. Increase in atrial natriuretic peptide production occurs under the influence of renin-angiotensin-aldosterone system and elevated AP.

Study Funding. The study was carried out within the frame of departmental research work of Ministry of Health of the Russian Federation 2015-2017 "Regulation mechanisms of physiological functions in experimental body states".

Conflicts of Interest. The authors have no conflicts of interest to declare.

\section{References}

1. Ogawa T., de Bold A. The heart as an endocrine organ. Endocr Connect 2014; 3(2): R31-R44, http://dx.doi. org/10.1530/EC-14-0012.

2. Ichiki T., Huntley B.K., Sangaralingham S.J., Burnett J.C. Jr. Pro-atrial natriuretic peptide: a novel guanylyl cyclase-A receptor activator that goes beyond atrial and B-type natriuretic peptides. JACC Heart Fail 2015; 3(9): 715-723, http://dx.doi.org/10.1016/j.jchf.2015.03.015.

3. de Bold A.J. Thirty years of research on atrial natriuretic factor: historical background and emerging concepts. Can J Physiol Pharmacol 2011; 89(8): 527-531, http://dx.doi. org/10.1139/y11-019. 
4. Kuhn M. Cardiac actions of atrial natriuretic peptide: new visions of an old friend. Circ Res 2015; 116(8): 12781280, http://dx.doi.org/10.1161/CIRCRESAHA.115.306325.

5. Nishikimi T., Kuwahara K., Nakao K. Current biochemistry, molecular biology, and clinical relevance of natriuretic peptides. J Cardiol 2011; 57(2): 131-140, http:// dx.doi.org/10.1016/j.jjcc.2011.01.002.

6. Zhou Y., Wu Q. Corin in natriuretic peptide processing and hypertension. Curr Hypertens Rep 2014; 16(2): 415, http:// dx.doi.org/10.1007/s11906-013-0415-7.

7. Arora P., Reingold J., Baggish A., Guanaga D.P., Wu C., Ghorbani A., Song Y., Chen-Tournaux A., Khan A.M., Tainsh L.T., Buys E.S., Williams J.S., Heublein D.M., Burnett J.C., Semigran M.J., Bloch K.D., Scherrer-Crosbie M., Newton-Cheh C., Kaplan L.M., Wang T.J. Weight loss, saline loading, and the natriuretic peptide system. J Am Heart Assoc 2015; 4(1): e001265, http://dx.doi.org/10.1161/ JAHA.114.001265.

8. Ogawa N., Komura H., Kuwasako K., Kitamura K., Kato J. Plasma levels of natriuretic peptides and development of chronic kidney disease. BMC Nephrol 2015; 16: 171, http:// dx.doi.org/10.1186/s12882-015-0163-9.

9. Galkina M.V., Baskina O.S., Bugrova M.L. The study of synthesis, accumulation and release processes of atrial and brain natriuretic peptides in experimental renovascular hypertension. Sovremennye tehnologii v medicine 2015; 7(2): 33-40, http://dx.doi.org/10.17691/stm2015.7.2.04.

10. Bugrova M.L. The study of atrial natriuretic peptide in different types of arterial hypertension in experiment. Morfologicheskie vedomosti 2015; 2: 28-34.

11. Arutiunov G.P., Sokolova A.V., Oganesova L.G. Experimental models of renal tubulointersitial damade in arterial hypertension. Klinicheskaya nefrologiya 2011; 2: 75-78.

12. Laffer C.L., Laniado-Schwartzman M., Wang M.H., Nasjletti A., Elijovich F. 20-HETE and furosemide-induced natriuresis in salt-sensitive essential hypertension. Hypertension 2003; 41(3 Pt 2): 703-708, http://dx.doi. org/10.1161/01.HYP.0000051888.91497.47.

13. Ventura N.M., Peterson N.T., Tse M.Y., Andrew R.D., Pang S.C., Jin A.Y. Molecular adaptations in vasoactive systems during acute stroke in salt-induced hypertension. Mol Cell Biochem 2015; 399(1-2): 39-47, http://dx.doi.org/10.1007/ s11010-014-2230-0.

14. Aaron K.J., Sanders P.W. Role of dietary salt and potassium intake in cardiovascular health and disease: a review of the evidence. Mayo Clin Proc 2013; 88(9): 987-995, http://dx.doi.org/10.1016/j.mayocp.2013.06.005.

15. Richardson S.I., Freedman B.I., Ellison D.H., Rodriguez C.J. Salt sensitivity: are view with a focus on nonHispanic blacks and Hispanics. J Am Soc Hypertens 2013; 7(2): 170-179, http://dx.doi.org/10.1016/j.jash.2013.01.003.

16. Weinberger M.H. Salt sensitivity is associated with an increased mortality in both normal and hypertensive humans. J Clin Hypertens (Greenwich) 2002; 4(4): 274-276, http:// dx.doi.org/10.1111/j.1524-6175.2002.00924.x.

17. Smirnova M.I., Oganov R.G., Gorbunov V.M., Deev A.D., Andreeva G.F. Masked inefficacy of arterial hypertension treatment: prevalence and predictors. Kardiovaskulyarnaya terapiya i profilaktika 2011; 10(6): 11-17.

18. Maksimov V.F., Korostyshevskaya I.M., Kurganov S.A., Markel' A.L., Rudenko N.S., lakobson G.S. Changes of right atrial myoendocrine cells during hypertension and after arterial pressure decrease. Tsitologiia 2014; 56(10): 725-734.
19. Torres-Courchoud I., Chen H.H. B-type natriuretic peptide and acute heart failure: fluid homeostasis, biomarker and therapeutics. Rev Clin Esp 2016; pii: S00142565(16)00025-4, http://dx.doi.org/10.1016/j.rce.2016.01.009.

20. Tripathi R., Wang D., Sullivan R., Fan T.H., Gladysheva I.P., Reed G.L. Depressed corin levels indicate early systolic dysfunction before increases of atrial natriuretic peptide/B-type natriuretic peptide and heart failure development. Hypertension 2016; 67(2): 362-367, http:// dx.doi.org/10.1161/HYPERTENSIONAHA.115.06300.

21. Hu W., Zhou P.H., Zhang X.B., Xu C.G., Wang W. Plasma concentrations of adrenomedullin and natriuretic peptides in patients with essential hypertension. Exp Ther Med 2015; 9(5): 1901-1908, http://dx.doi.org/10.3892/ etm.2015.2345.

22. Macheret F., Heublein D., Costello-Boerrigter L.C., Boerrigter G., McKie P., Bellavia D., Mangiafico S., Ikeda Y., Bailey K., Scott C.G., Sandberg S., Chen H.H., Malatino L., Redfield M.M., Rodeheffer R., Burnett J. Jr., Cataliotti A. Human hypertension is characterized by a lack of activation of the antihypertensive cardiac hormones ANP and BNP. J Am Coll Cardiol 2012; 60(16): 1558-1565, http://dx.doi. org/10.1016/j.jacc.2012.05.049.

23. Mifune H., Nishi Y., Tajiri Y., Yabuki A. Different A-type natriuretic peptide level in five strains of mice. J Vet Med Sci 2012; 74(4): 499-502, http://doi.org/10.1292/jvms.11-0451.

24. Abrosimov D.A., Yakovleva E.I., Bugrova M.L. Quantitative assay of brain natriuretic peptide in rat cardiomyocytes in the early postreperfusion period. Cell and Tissue Biology 2015; 9(4): 336-339, http://dx.doi.org/10.1134/ s1990519x15040021.

25. Sato M., Mikamo A., Kurazumi H., Suzuki R., Murakami M., Kobayashi T., Yoshimura K., Hamano K. Ratio of preoperative atrial natriuretic peptide to brain natriuretic peptide predicts the outcome of the maze procedure in mitral valve disease. J Cardiothorac Surg 2013; 8: 32, http://dx.doi. org/10.1186/1749-8090-8-32.

26. Petrov S.V., Raykhlin N.T. Rukovodstvo po immunogistokhimicheskoy diagnostike opukholey cheloveka [Guide to immunohistochemical diagnosis of human tumors]. Kazan; 2000; 287 p.

27. Biserova N.M. Metody vizualizatsii biologicheskikh ul'trastruktur. Podgotovka biologicheskikh ob"ektov dlya izucheniya s pomoshch'yu elektronnykh i fluorestsentnykh konfokal'nykh lazernykh mikroskopov [Imaging methods of biological ultrastructures. Preparation of biological objects for the study using electron and fluorescent confocal laser microscopes]. Moscow: Tovarishchestvo nauchnykh izdaniy KMK; 2013; 104 p.

28. Rakhcheeva M.V., Bugrova M.L. Changes in the proportion of A- and B-types of granules containing atrial and brain natriuretic peptides in atrial myocytes in vasorenal hypertension in rats. Tsitologiia 2010; 52(8): 629-633.

29. Babkin A.P., Gladkikh V.V., Kurbatova T.L. Salt sensitivity of arterial hypertension as a predictor of antihypertensive therapy efficacy. Mezhdunarodnyy meditsinskiy zhurnal 2010; 16(3): 49-52.

30. Felder R.A., White M.J., Williams S.M., Jose P.A. Diagnostic tools for hypertension and salt sensitivity testing. Curr Opin Nephrol Hypertens 2013; 22(1): 65-76, http://dx.doi. org/10.1097/MNH.0b013e32835b3693.

31. Volkov V.S., Poselyugina O.B., Nilova S.A., Rokkina C.A. Blood pressure level and salt intake in 
hypertensive patients. Arterial'naya gipertenziya 2011; 17(1): 69-73.

32. Osipova I.V., Miroshnichenko A.I., Pyrikova N.V., Antropova O.N., Kulikov V.P., Aleksentseva A.V. Long-term variability of blood pressure and risk factors in men with stressinduced hypertension. Arterial'naya gipertenziya 2014; 20(2): 92-100.

33. Armstrong D.W., Tse M.Y., O'Tierney-Ginn P.F., Wong P.G., Ventura N.M., Janzen-Pang J.J., Matangi M.F., Johri A.M., Croy B.A., Adams M.A., Pang S.C. Gestational hypertension in atrial natriuretic peptide knockout mice and the developmental origins of salt-sensitivity and cardiac hypertrophy. Regul Pept 2013; 186: 108-115, http://dx.doi. org/10.1016/j.regpep.2013.08.006.

34. Bugrova M.L. Atrial and brain natriuretic peptides of cardiac muscle cells in postreperfusion period in rats. Tsitologiia 2016; 58(2): 129-134.

35. Armaly Z., Assady S., Abassi Z. Corin: a new player in the regulation of salt-water balance and blood pressure. Curr Opin Nephrol Hypertens 2013; 22(6): 713-722, http://dx.doi. org/10.1097/01.mnh.0000435609.35789.32.

36. Cavallero S., González G.E., Seropian I.M., Cerrudo C.S., Matorra F., Morales C., Hertig C.M., Puyó A.M., Fernández B.E., Gelpi R.J. Ventricular function and natriuretic peptides in sequentially combined models of hypertension. Am J Physiol Heart Circ Physiol 2010; 298(4): H1290-H1299, http://dx.doi.org/10.1152/ajpheart.00911.2009.

37. Selivanova G.V., Vlasova T.D., Khirmanov V.N., Krutikov A.N. Changes in the cytochemical and morphometric characteristics of the myocytes in the right heart of the rat in adrenal-regeneration hypertension. Tsitologiia 1995; 37(5-6): 415-423.

38. Costa M.V., Fernandes-Santos C., Faria T. da S., Aguila M.B., Mandarim-de-Lacerda C.A. Diets rich in saturated fat and/or salt differentially modulate atrial natriuretic peptide and renin expression in C57BL/6 mice. Eur J Nutr 2012; 51(1): 89-96, http://dx.doi.org/10.1007/s00394-011-0196-1.

39. Kobori H., Nishiyama A., Abe Y., Navar L.G. Enhancement of intra renal angiotensinogen in Dahl saltsensitive rats on high salt diet. Hypertension 2003; 41(3): 592559, http://dx.doi.org/10.1161/01.HYP.0000056768.03657.B4.

40. Bayorh M.A., Ganafa A.A., Emmett N., Socci R.R., Eatman D., Fridie I.L. Alterations in aldosterone and angiotensin II levels in salt-induced hypertension. Clin Exp Hypertens 2005; 27(4): 355-367, http://dx.doi.org/10.1081/ ceh- 57423.

41. Le Corvoisier P., Adamy C., Sambin L., Crozatier B., Berdeaux A., Michel J.B., Hittinger L., Su J. The cardiac reninangiotensin system is responsible for high-salt diet-induced left ventricular hypertrophy in mice. Eur J Heart Fail 2010; 12(11): 1171-1178, http://dx.doi.org/10.1093/eurjhf/hfq146.

42. Tamura K., Chiba E., Yokoyama N., Sumida Y.,
Yabana M., Tamura N., Takasaki I., Ishii M., Horiuchi M., Umemura S. Renin-angiotensin system and fibronectin gene expression in Dahl Iwai salt-sensitive and saltresistant rats. J Hypertens 1999; 17(1): 81-89, http://dx.doi. org/10.1097/00004872-199917010-00013.

43. Temsah R., Nemer M. GATA factors and transcriptional regulation of cardiac natriuretic peptide genes. Regul Pept 2005; 128(3): 177-178, http://dx.doi.org/10.1016/j. regpep.2004.12.026.

44. Vuolteenaho O., Ala-Kopsala M., Ruskoaho H. BNP as a biomarker in heart disease. Adv Clin Chem 2005; 40: 1-36, http://dx.doi.org/10.1016/s0065-2423(05)40001-3.

45. Bramham K., Seed P.T., Lightstone L., NelsonPiercy C., Gill C., Webster P., Poston L., Chappell L.C. Diagnostic and predictive biomarkers for pre-eclampsia in patients with established hypertension and chronic kidney disease. Kidney Int 2016; 89(4): 874-885, http://dx.doi. org/10.1016/j.kint.2015.10.012.

46. Goetze J.P. Biosynthesis of cardiac natriuretic peptides. Results Probl Cell Differ 2010; 50: 97-120, http://dx.doi. org/10.1007/400_2009 25.

47. Yuan K., Kim S.Y., Oh Y.B., Yu J., Shah A., Park B.H., Kim S.H. Upregulation of ANP and NPR-C mRNA in the kidney and heart of eNOS knockout mice. Peptides 2010; 31(7): 1319-1325, http://dx.doi.org/10.1016/j. peptides.2010.04.008.

48. Akhmedkhanova A.A. Features of kidney response on water and salt load in spinal animals. Nefrologiya i dializ 2003; 5(3): 249.

49. Sun Y., Deng T., Lu N., Yan M., Zheng X. B-type natriuretic peptide protects cardiomyocytes at reperfusion via mitochondrial calcium uniporter. Biomed Pharmacother 2010; 64(3): 170-176, http://dx.doi.org/10.1016/j. biopha.2009.09.024.

50. Pan X., Liu J., Nguyen T., Liu C., Sun J., Teng Y., Fergusson M.M., Rovira I.I., Allen M., Springer D.A., Aponte A.M., Gucek M., Balaban R.S., Murphy E., Finkel T. The physiological role of mitochondrial calcium revealed by mice lacking the mitochondrial calcium uniporter. Nat Cell Biol 2013; 15(12): 1464-1472, http://dx.doi.org/10.1038/ncb2868.

51. Arjamaa O., Nikinmaa M. Hypoxia regulates the natriuretic peptide system. Int $J$ Physiol Pathophysiol Pharmacol 2011; 3(3): 191-201.

52. Casserly B., Pietras L., Schuyler J., Wang R., Hill N., Klinger J. Cardiac atria are the primary source of ANP release in hypoxia-adapted rats. Life Sci 2010; 87(11-12): 382-389, http://dx.doi.org/10.1016/j.Ifs.2010.07.013.

53. Fujii Y., Ishino K., Tomii T., Kanamitsu H., Fujita Y., Mitsui H., Sano S. Atrionatriuretic peptide improves left ventricular function after myocardial global ischemiareperfusion in hypoxic hearts. Artif Organs 2012; 36(4): 379386, http://dx.doi.org/10.1111/j.1525-1594.2011.01358.x. 